\title{
A Testament to the Power of Resilience and Friendship Portrayed in Stephen King's The Institute
}

Dr. A.J Manju

Associate Professor and Head

M.A., M.Phil., Ph.D., B.Ed.

Sree Narayana Guru College

Coimbatore, Tamil Nadu, India

manjumadhu57@gmail.com

\section{Anas P M}

M. Phil Scholar

Department of English

Sree Narayana Guru College

Coimbatore, Tamil Nadu, India

Abstract

We all face Hardships and difficult situations in our life. It's all about the ups and downs in our day to day life. During these times we may be feeling exhausted and worried. But all that matters is that what we have learned from that tough situation. Resilience is defined as how we bounce back quickly from a difficult situation. The power of resilience arises when we face situational problems, major life problem and day to day problems. Friends are a major element in comforting us during our difficult times. Friends bring more happiness to our lives than virtually anything else. Friendships have a huge impact on our mental health and happiness. Good friends relieve stress, provide comfort and joy, and prevent loneliness and isolation. 
The Institute (2019) is a science fiction horror novel written by Stephen king. It is one of his terrifying novels yet. Many of his works are transformed into movies and television series. The main focus of this novel is on the power of resilience and friendship among the children who are being kidnapped from their homes and being held captive under a sinister establishment called The Institute. The story is written by taking the ideas of a fictitious child abusing institution where gifted children from all over the country are taken in and they are being forced to undergo atrocious medical experiments. Most of the children have super powers of Telepathy or Telekinesis. That's the reason they are all here in the Institute. The authorities in the Institute want the children to master their powers so that they can be used in wars. There is no hope of escape for the children, yet they are all finally escaped by the power of resilience and friendship shown by Luke Ellis, the main character in the novel and his friends.

Keywords: Children, Resilience, Institute, Friendship, Friends

Introduction

The main character in the story is a boy named Luke Ellis who lives with his parents in the fictitious town of DuPray, Minnesota. Luke was not an ordinary kid, he was a gifted child with certain powers of moving things with his mind (Telekinesis). At certain intervals his powers get triggered and his parents were always worried about that. They encourage him to keep his powers a secret in front of others. Life isn't easy for a gifted kid with Telekinetic powers. He was a very smart and intelligent kid who can absorb two semesters worth of extremely difficult postgraduate work in a single week. Even though Luke had everything, he was not happy inside. All he wanted was to have a normal life like the other children and to have real friends so that his parents will not be worried about him.

A New Home 
On a cold night in June Three people named Denny, Michelle and Robin broke into the house of Luke Ellis. They killed his parents and snatched him away. The next day he woke up in a room similar to his except that it had no windows. At first he thought it was a dream, but soon he realized that it was not his home. He got out of the bed and saw that his clothes were on the chair, where his mom had put them the night before. He put on the sneakers which was not his but fitted perfectly. He opened the door and entered in to a cinderblock instead of wood paneling like that in his house. He walked through the corridor and met a girl named Kalisha Benson. She was wearing bellbottoms and a shirt with puffy sleeves. She was black and almost of his own age. He learned from her that he was no longer anywhere near to his home and the place he was in is called the Institute, where children with special powers of Telepathy or Telekinesis are taken in and being experimented until they acquire control over their powers. She explained him the various tests that they all have to undergo in the Institute and advised him to do exactly as they say. She also told him that the Institute is divided into two blocks, the Front Half and the Back Half. As long as the testing is over they will have to go to the Back Half, where children go and never come back. He looked back the way he came and saw a lot of motivational posters. There were three more kids in the Front Half named Nicky, George and Iris. There were also care takers in the Institute and he met one of them named Maureen. The kids are allowed to play in the play area and to sit in the canteen.

Luke entered in to the playground along with Kalisha and met the other kids. Soon they all made friends with one another. They all hated to be here in the Institute, the only thing which was keeping them alive was the friendship among them. The playground was surrounded by a chain link fence ten feet high, and there was cameras peering down at two of the corners. Beyond the fence there was nothing but pine forest. Mrs Sigsby was the head of the Institute. She had no other intention except to make the children fit for them and she 
considered them like mere test subjects. Luke knew that the people here track the kids, runs tests on them and send the results to the malicious Back Half. One day as they all were sitting in the canteen a woman named Gladys dressed in a uniform came over to Luke and asked him to come with her. He knew it was for the experiment called as Shots for Dots. When they give the kids the shots, it makes them see dots. The staff monitors id they can see them. Luke gets his first set of shots. The kids get tokens for doing what they are told to do and they can buy drinks and snacks from the canteen using the tokens.

\section{Maureen and Avery}

One day a new kid named Avery Dixon came to the Front Half who was only ten years old. Luke was asked to help him understand the process of experiments. Avery had strong Telepathic abilities. All the kids in the Institute knows that Maureen is not at all interested in her job in the Institute. She is only doing this to pay off her husband's debts. Luke found out that she needs money for sending her son to college and also for his treatment. The next day Luke had another set of those experiments which is called shots for dots. They gave him another injection and showed him dots and when he refused to cooperate, they hit and tortured him. After the experiment he realized that he has now some sort of Telepathic abilities also. But he kept it as a secret from the authorities. He discussed it with his friends and understands that it hasn't happened to other kids. Luke researches and finds out that soon all of his friends including him will be in Back Half unless he does something about it. He realized that everything the Institute officials was telling them was a big lie and his parents are dead.

Escape from the Alcatraz

Luke started to plan his way of escape. Now all other kids were in the Back Half except Luke and Avery. He managed to get one of the elevator pass. Avery was able to 
deliver messages from the Back Half via Telepathy. Luke now had all the information about the Back Half. He understood that in the Back Half the kids are put to work. They are being used as war machines. Luke managed to fool the authorities believe that he doesn't have any Telepathic abilities. Maureen decided to help Luke to escape. She told him that he will have only three days after they stop testing him and he will be forced to enter the Back Half. So if he is planning anything he needs to do it while he is in the Front Half. He found out that there is a weak spot under the fence in the playground area. He decided to sneak off through that fence and he succeeded in it. Outside the fence Luke realizes that the staffs of the Institute will be living around, so he decided to go as far as possible. He followed the direction which was told by Maureen and makes his way to the nearby town. He gets into a boxcar with furniture pads in it and the train rolled away. He later has to switch cars and eventually he ends up headed toward DuPray, South Carolina.

Hell is waiting

The Institute officials have found out about Luke's escape and decided to send officials for searching him. They tortured Avery for finding about Luke and he lies a little. Eventually they found out that Luke was in a police station in DuPray and decided to get there and snatch him. Luke told about everything regarding the Institute and the police officials were confused whether to believe him or not. Later he showed them a pen drive which was given by Maureen to him. It contained all the evidence they wanted. Mrs Sigsby and her team were now outside the police station. They decided to kill every police officials including Luke. After a long shoot-out many were dead on both sides. Luke and a police officer named Tim Jamieson managed to capture Mrs Sigsby and her doctor. They decided to go to the Institute and free all the children. Back at the Institute they were ambushed and Mrs Sigsby was killed. Meanwhile all the children in the Back Half decided to put an end to the Institute. They used their enhanced powers combined to burst out locked doors and levitated 
the entire building crushing all the officials and some children including Avery. When the dust settled, there were some Back Half survivors. Of the kids, Helen, Kalisha, George and Nicky have survived. Luke joined them.

An unexpected visit

Three months later a man came to visit them and asked them not to disclose any evidence regarding the Institute to the public. He said that there are many Institutes like the one that they destroyed all over the earth and said that the Institute was set up for the safety of the world. However, Luke tells the Man that this system is defective. Kalisha and Nicky are returned to various family members, but Luke had no relatives so he stayed with Tim Jamieson and Wendy. The story ends with him thinking about Avery and how heroic he was.

\section{Conclusion}

The story teaches us that Resilience and friendship are the two characteristics to have if you want to be successful in life. It's about the capacity to go through difficulties and still have the will to keep moving forward. We will go through failure before we can succeed, that's the reality of life. Friendship is an element which helps us to be resilient. It's the friendship and resilient nature of Luke that helped him to escape from the sinister Institute. He had to face several difficulties like the murder of his parents, torturing experiments and brutality of the people in the Institute, but still he was able to withstand all those negative aspects and succeed in his plan to bring the Institute down. He never felt withdrawn or helpless. His friends were always there for him no matter what the situation was. They always updated him about the information from the Back Half and it was Kalisha who kept him company when he first entered the Institute. Resilience is not simply about bouncing back from difficulties, it's about dealing with the troublesome waves while transforming with integrity in response to changing situations. One should be aware of the present moment. Mindfulness allows us to choose how to take action and respond to a situation. 
The novel makes us realize of the need to be Resilient during tough situations in our life. As happiness and sorrow are the two sides of the same coin, we must move forward in order to be succeeded in life. The characters in the story are so lively as if we will be seeing them in front of our eyes while we read this masterpiece. This is a story which can be perused by all age groups. Readers must be aware that there is strong violence against children in the book. 


\section{Works Cited}

Stephen King's The Institute published by Hodder \& Stoughton Ltd London, 2019 